\title{
Mutants of Bacillus stearothermophilus defective in the uptake and metabolism of acetate
}

\author{
Philip R. Mallinder $\dagger$ and ANNe Moir* \\ The Krebs Institute for Biomolecular Research, Department of Molecular Biology and Biotechnology, University of \\ Sheffield, Sheffield S10 2TN, UK
}

(Received 31 August 1990; revised 29 November 1990; accepted 11 December 1990)

\begin{abstract}
Mutants unable to utilize acetate as sole source of carbon and energy were isolated from ethyl-methanesulphonatemutagenized cultures of a prototrophic Bacillus stearothermophilus strain. Three groups of mutants had identifiable defects. Thirteen of the mutants lacked one or both enzymes of the inducible anaplerotic glyoxylate shunt, and three mutants were auxotrophic for isoleucine and valine when grown on acetate, in a manner analogous to acetohydroxyacid synthase I mutants of enteric bacteria. One mutant was defective specifically in acetate uptake, providing direct evidence for an acetate transport system in B. stearothermophilus. The acetate uptake system was uncoupler-sensitive and had a relatively high $K_{\mathrm{m}}$ (in the range 300-350 $\mu \mathrm{M}$ ). Escherichia coli was also shown to possess a saturable acetate uptake system, but its $K_{\mathrm{m}}$ was much lower $(15 \mu \mathrm{M})$.
\end{abstract}

\section{Introduction}

The prototroph Bacillus stearothermophilus var. nondiastaticus (Epstein \& Grossowicz, 1969) utilizes a wide variety of compounds, including acetate, as single carbon and energy sources. Acetate is also the major product of overflow metabolism when glucose-grown chemostat cultures are phosphate, sulphur, magnesium or potassium limited. Under potassium limitation, $40 \%$ of the input glucose carbon can be converted to acetate (Pennock \& Tempest, 1988).

In the work described in this paper, mutants in acetate metabolism were sought with the hope of redirecting the overflow metabolism; in particular, it was intended to isolate acetate kinase and phosphotransacetylase mutants, blocked in the interconversion of acetyl-CoA and acetate.

Fluoroacetate, a toxic analogue of acetate, has been used to select for mutants of Escherichia coli and Salmonella typhimurium unable to grow on acetate (Brown et al., 1977; Guest, 1979; LeVine et al., 1980). Fluoroacetate is converted intracellularly into fluorocitrate, which inhibits aconitase (Mager et al., 1955,

\footnotetext{
† Present address: Department of Biochemistry, University of Leicester, Leicester LE1 7RH, UK.

Abbreviations: CCCP, carbonyl cyanide $m$-chlorophenylhydrazone; Fac $^{\mathbf{R}}$, fluoroacetate resistant.
}

Glusker, 1971). Mutants resistant to fluoroacetate have been identified as defective in acetate kinase (ack), phosphotransacetylase (pta) or both; some resistant mutants with normal levels of both these enzymes have also been described (Guest, 1979). Screens for acetate non-utilizers have produced similar genotypes to the above and, in addition, mutants defective in the glyoxylate cycle (Wilson \& Maloy, 1987).

This paper describes the results of selection and screening procedures adopted to isolate $B$. stearothermophilus mutants with a functional TCA cycle but defects in the ability to utilize acetate as sole carbon source. One novel mutant type defective in acetate transport was identified, focussing our attention on potential acetate transport systems in bacteria.

\section{Methods}

\section{Bacteria. The bacterial strains used are listed in Table 1}

Bacteriological media. B. stearothermophilus was routinely grown at $55^{\circ} \mathrm{C}$ unless otherwise stated. Generally, the strains were subcultured on nutrient agar plates (Oxoid) and TSY medium (Liao et al., 1986) was used as a rich broth for liquid cultures. Evans' minimal salts medium (Evans et al., 1970) was modified as described by Pennock \& Tempest (1988) and was solidified where appropriate with agar to $1.75 \%(w / v)$. Sole sources of carbon and energy were added to minimal salts to the following final concentrations: glucose, $5 \mathrm{~g} \mathrm{1}^{-1}$; sodium succinate, $60 \mathrm{~mm}$; sodium acetate, sodium malate and sodium lactate, $40 \mathrm{~mm}$. 
Table 1. Bacterial strains

\begin{tabular}{|c|c|c|}
\hline Strain & Genotype & Source or reference \\
\hline $\begin{array}{l}\text { B. stearothermophilus } \\
\text { var. nondiastaticus }\end{array}$ & Wild-type & $\begin{array}{l}\text { Pennock \& Tempest } \\
\text { (1988) }\end{array}$ \\
\hline AM 1032 & icl- 124 & \\
\hline AM1033 & icl-209 & \\
\hline AM1034 & icl-210 & \\
\hline AM 1035 & $i c l-653$ & \\
\hline AM 1049 & icl-567 & \\
\hline AM1036 & mas-526 & \\
\hline AM 1037 & icl mas-331 & \\
\hline AM 1038 & icl mas-539 & \\
\hline AM1039 & icl mas-585 & This paper \\
\hline AM 1040 & icl mas-603 & \\
\hline AM1041 & icl mas-606 & \\
\hline AM 1042 & icl mas -613 & \\
\hline AM1043 & icl mas-518 & \\
\hline AM1045 & ace-333; ilv-requiring & \\
\hline AM1046 & ace-494; ilv-requiring & \\
\hline AM 1047 & ace- 640 ; ilv-requiring & \\
\hline AM1048 & ace-271; uptake mutant & \\
\hline \multicolumn{3}{|l|}{ E. coli } \\
\hline JRG911 & Wild-type & \\
\hline JRG 1061 & ack & \\
\hline JRG 1078 & ack pta & Guest (19/9) \\
\hline JRG 1089 & pta & \\
\hline
\end{tabular}

Preparation of spores and mutagenesis. Spores were prepared by spreading $200 \mu \mathrm{l}$ of a mid-exponential TSY culture of $B$. stearothermophilus onto lactate minimal plates and incubating at $55^{\circ} \mathrm{C}$ for $24-36 \mathrm{~h}$. Spores and any remaining vegetative cells were harvested by suspension in $10 \mathrm{ml}$ of sterile distilled water, washed by repeated centrifugation and resuspension in $30 \mathrm{ml}$ of sterile distilled water, and resuspended in sterile distilled water. The suspension was then heated at $96^{\circ} \mathrm{C}$ for $10 \mathrm{~min}$, cooled and stored at $4{ }^{\circ} \mathrm{C}$.

Spores were mutagenized according to the method of Ito \& Spizizen (1971). The spore preparation was diluted to $10^{8}$ c.f.u. $\mathrm{ml}^{-1}$ in $0 \cdot 1 \mathrm{M}$ sodium phosphate buffer, $\mathrm{pH}$ 7.0. Ethyl methanesulphonate (EMS) was added to a final concentration of $450 \mathrm{~mm}$, and the suspension incubated for $1 \mathrm{~h}$ at $30^{\circ} \mathrm{C}$, washed three times in sodium phosphate buffer, and stored at $4{ }^{\circ} \mathrm{C}$. Growing cells were recovered from the spores following $5 \mathrm{~h}$ incubation in TSY at $55^{\circ} \mathrm{C}$; the resulting cultures were either plated immediately or stored at $-20^{\circ} \mathrm{C}$ in the presence of $15 \%(\mathrm{v} / \mathrm{v})$ glycerol.

Vegetative cells were also mutagenized: cells grown to midexponential phase at $55^{\circ} \mathrm{C}$ in TSY were equilibrated at $42^{\circ} \mathrm{C}$, EMS was added to $750 \mathrm{~mm}$ and the cells incubated for $1 \mathrm{~h}$ at $42^{\circ} \mathrm{C}$ before washing and plating.

Preparation of extracts and enzyme assays. B. stearothermophilus cells $(25 \mathrm{ml})$ were grown in minimal media, with the sole carbon source indicated, to an $\mathrm{OD}_{600}$ of $0 \cdot 7$. Cells grown on succinate and then induced in the presence of acetate were grown in succinate minimal medium to an $\mathrm{OD}_{600}$ of 0.7 , harvested, resuspended in prewarmed acetate minimal medium and incubated for a further hour. Cells $(10 \mathrm{ml})$ were then harvested, washed in $50 \mathrm{~mm}$-potassium phosphate buffer,

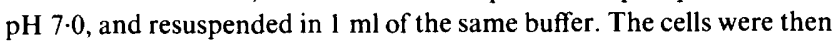
sonicated and the extracts centrifuged at 12000 r.p.m. for $5 \mathrm{~min}$ at $4^{\circ} \mathrm{C}$; the supernatants were retained on ice and assayed immediately. Assays on extracts of $B$. stearothermophilus and E. coli cells were done at $48{ }^{\circ} \mathrm{C}$ and $37^{\circ} \mathrm{C}$ respectively. Acetate kinase was measured according to the method of Nishimura \& Griffith (1981), by coupling the formation of
ATP with hexokinase and glucose-6-phosphate dehydrogenase: the formation of NADPH was measured at $340 \mathrm{~nm}$. Phosphotransacetylase was assayed according to the method of Wofford et al. (1986), measuring the appearance of the thioester bond of acetyl-CoA at $233 \mathrm{~nm}$. Isocitrate lyase was assayed in the forward direction according to Reeves et al. (1971), by measuring the formation of glyoxylic acid phenylhydrazone at $324 \mathrm{~nm}$. The malate synthase assay of Reeves $e t$ al. (1971) was modified to measure the formation of free CoA. 5,5'Dithio(2-nitrobenzoic acid) was substituted for the $20 \mathrm{~mm}$-ATP, and $20 \mathrm{~mm}$-pyrophosphate buffer, $\mathrm{pH} 8.0$, was used instead of $1 \mathrm{M}$ Tris $/ \mathrm{HCl}, \mathrm{pH} 8 \cdot 0$. The increase of absorbance was measured at $412 \mathrm{~nm}$. Soluble protein was measured according to the method of Bradford (1976), using bovine serum albumin as a standard.

Acetate uptake studies. Cells $(25 \mathrm{ml})$ were grown in glucose plus acetate minimal medium to an $\mathrm{OD}_{600}$ of 0.7 . They were transferred to prewarmed centrifuge tubes and pelleted briefly in a bench centrifuge at $37^{\circ} \mathrm{C}$. The pellets were then resuspended in prewarmed Evans' salts $\left(55^{\circ} \mathrm{C}\right)$, centrifuged at $37^{\circ} \mathrm{C}$, resuspended in $300 \mu \mathrm{l}$ of minimal salts and maintained at $55^{\circ} \mathrm{C}$. To measure acetate uptake, $100 \mu$ lof the cell suspension was added to $2 \mathrm{ml}$ of prewarmed Evans' salts and the cells were aerated at $50^{\circ} \mathrm{C}$ for $7 \mathrm{~min} .\left[2-^{14} \mathrm{C}\right]$ Acetate $[20 \mu \mathrm{l} ; 38 \mathrm{~mm}, 20 \mu \mathrm{Ci}$ $\left.\mathrm{ml}^{-1}\left(740 \mathrm{kBq} \mathrm{ml} l^{-1}\right)\right]$ was added, and then $100 \mu \mathrm{l}$ samples were removed at $10 \mathrm{~s}$ intervals and rapidly filtered through nitrocellulose discs, under pressure. The discs were washed with $10 \mathrm{ml}$ of buffer (50 mM-potassium phosphate buffer, $\mathrm{pH} 7 \cdot 0,10 \mathrm{mM}$-sodium acetate) to wash off unincorporated radiolabelled acetate. These discs were then dissolved in scintillation fluid and the radioactivity measured in a Beckman L51801 liquid scintillation counter. To determine cell protein, $25 \mu \mathrm{l}$ of cells was added to $4 \mathrm{ml}$ of water, $20 \mu \mathrm{g}$ of lysozyme was added and the mixture incubated at $37^{\circ} \mathrm{C}$ for $20 \mathrm{~min}$. A $100 \mu \mathrm{l} \mathrm{sample}$ was removed for protein estimation.

Reagents. The bacteriological media were obtained from Oxoid and Difco. All chemicals used were of analytical reagent grade (Sigma or $\mathrm{BDH}$ ) except ADP (Boehringer). The nitrocellulose discs (Millipore) had a pore size of $0.45 \mu \mathrm{m}$. Scintillation fluid was Cocktail T 'Scintran' from $\mathrm{BDH} .\left[2-{ }^{1+} \mathrm{C}\right]$ Acetate and $\mathrm{L}-\left[1,4,5-{ }^{3} \mathrm{H}\right] \mathrm{leucine}$ were obtained from Amersham.

\section{Results}

\section{Mutagenesis of B. stearothermophilus}

Incubation of $B$. stearothermophilus spores in $450 \mathrm{~mm}^{-}$ EMS at $30{ }^{\circ} \mathrm{C}$ for $1 \mathrm{~h}$ resulted in about $50 \%$ kill, with $10 \%$ of the survivors being auxotrophs as estimated by replica plating on minimal medium. B. stearothermophilus spores are more susceptible to the lethal and mutagenic effects of EMS than are spores of B. subtilis 168 (Ito \& Spizizen, 1971) or B. cereus NCIB 8122 (Necasek et al., 1966). Incubation of $B$. stearothermophilus vegetative cells in $75 \mathrm{~mm}$-EMS for $1 \mathrm{~h}$ at $42{ }^{\circ} \mathrm{C}$ gave approximately $99 \%$ kill, and about $6 \%$ of the survivors were auxotrophs. Prolonged incubation in EMS of either spores or vegetative cells ultimately results in the survival of only EMS-resistant mutants (data not shown).

\section{Isolation of acetate-negative mutants}

Two general approaches involving selection and screening, respectively, were adopted. Fluoroacetate-resistant 
$\left(\mathrm{Fac}^{\mathrm{R}}\right)$ mutants were selected on minimal lactate medium containing 125-175 mM-fluoroacetate (the minimum selective concentration was $100 \mathrm{mM}$, compared with the 10-50 mM range reported for $E$. coli selection by Brown et al., 1977). Resistant colonies ( 1 per $10^{5}$ cells) were then purified on glucose minimal medium and transferred to plates containing acetate, lactate, succinate or glucose as sole carbon sources. TCA cycle mutants could be excluded by confirming the ability of strains to grow on glucose, lactate and succinate as carbon sources.

Mutants that failed to grow on acetate but that could grow on all the other carbon sources $\left(\right.$ Ace $\left.^{-}\right)$represented $5-10 \%$ of the possible $\mathrm{Fac}^{\mathrm{R}}$ colonies tested. Mutants in the 100 and 300 series came from the same mutagenized spore preparation, and those in the 200 and 400 series were derived from a second, independently mutagenized, spore population.

In the second approach, colonies derived from mutagenized spores or cells were replica plated from TSY, minimal succinate or minimal lactate media to minimal acetate; potential Ace $^{-}$colonies were then purified on minimal glucose and rechecked on the various carbon sources to yield the 500 and 600 series mutants, respectively.

\section{Glyoxylate pathway mutants}

Table 2 shows the activities of isocitrate lyase and malate synthase in wild-type $B$. stearothermophilus grown on different carbon sources. The enzymes of the glyoxylate pathway are present at very low levels in succinategrown cells, but are high in acetate-grown cells, as would be expected. The presence of both carbon sources led to intermediate expression levels, considerably lower than in acetate-grown cells. Because Ace ${ }^{-}$mutants could not be cultured in these conditions, mutant and wild-type cells grown in succinate medium were then induced in acetate medium for $1 \mathrm{~h}$ before assay. The wild-type showed at least as high an activity for acetate kinase and about one-third of the activity of malate synthase compared with the acetate-grown strain. Twenty-four mutants showing $\mathrm{Ace}^{-}$phenotypes from all the isolation procedures were tested for isocitrate lyase and malate synthase activity. Thirteen of these mutants had decreased activities in one or both of the glyoxylate pathway enzymes (Table 2). The mutants of class 1 were defined as isocitrate lyase (icl) mutants; class $1 \mathrm{~b}$ represents a leaky mutant with some residual activity. One mutant was defective only in malate synthase (mas) activity (class 2). The largest group, class 3 , consisted of mutants defective in both activities (icl mas). One mutant retained some activity of both enzymes. Regulatory, polar or deletion mutations could be responsible for the phenotype of class 3 mutants; the relative infrequency of simple malate synthase mutants may suggest that mutations in this gene frequently have polar effects, and that the $i c l$ gene lies downstream of mas in an operon analogous to the situation in $E$. coli and $S$. typhimurium. On the basis of these results, over half the $\mathrm{Ace}^{-}$mutants isolated were defective in the glyoxylate pathway.

\section{Screen for acetate kinase or phosphotransacetylase mutants}

Extracts of B. stearothermophilus cells grown on glucose and then for $1 \mathrm{~h}$ in acetate contain levels of acetate kinase $\left[2 \mu \mathrm{mol} \mathrm{min}^{-1} \text { (mg protein }\right)^{-1}$ ] and phosphotransacetylase $\left[6 \mu \mathrm{mol} \mathrm{min}^{-1}(\mathrm{mg} \text { protein })^{-1}\right]$ comparable to

Table 2. Glyoxylate pathway enzyme activities in B. stearothermophilus

Results are means of at least two experiments.

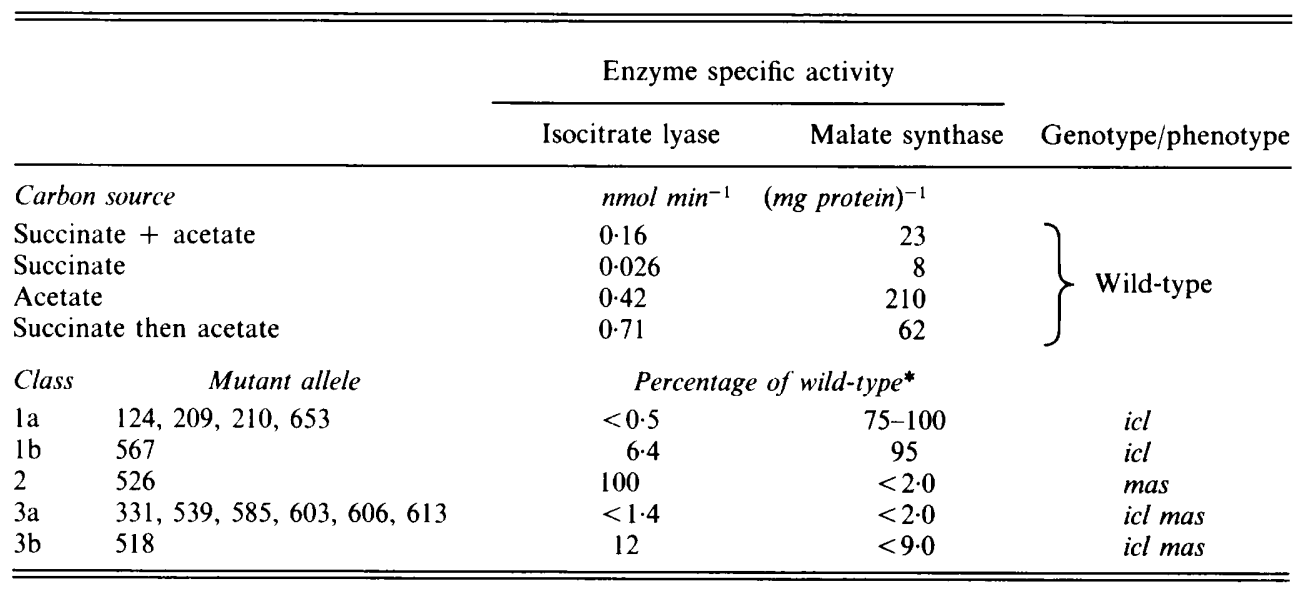

* All mutants were grown on succinate then acetate as above. 
those of E. coli JRG911 grown under similar conditions

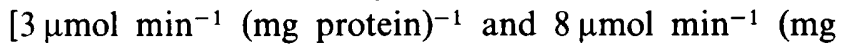
protein $)^{-1}$, respectively]. To confirm the validity of the assay procedure, E. coli acetate kinase (ack) and phosphotransacetylase (pta) mutants JRG1061, 1078 and 1089 (Guest, 1979) were analysed; the estimated levels of phosphotransacetylase in pta mutants was $<2 \%$ that of wild-type; residual activities of acetate kinase in ack mutants, however, were $30 \%$ of wild-type.

Thirty-eight $B$. stearothermophilus mutants derived from the various isolation procedures were assayed; most of those chosen for study could grow on both succinate and lactate, although several that did not were also screened in case the phenotypes of ack or pta mutants might differ from the predicted simple $\mathrm{Ace}^{-}$. All thirtyeight mutants tested had wild-type activities of both enzymes.

\section{Isoleucine- and valine-requiring mutants}

Several acetate-negative mutants of E. coli (Dailey \& Cronan, 1986) and S. typhimurium (Dailey et al., 1987; Wilson \& Maloy, 1987) will grow on acetate if the medium is supplemented with isoleucine and valine. These mutants lack the isoenzyme acetohydroxyacid synthase I. This enzyme catalyses the first step in the biosynthetic pathways of isoleucine and valine, and this particular isoenzyme is essential for the pathway to function in acetate-grown (but not glucose-grown) cells.

Forty-three Ace $^{-}$mutants of B. stearothermophilus were tested; three (AM1045, AM1046, AM1047) were found to be $\mathrm{Ace}^{+}$if isoleucine and valine were added to the growth medium at $50 \mu \mathrm{g} \mathrm{ml}^{-1}$. These are presumed to be analogous to the mutants of similar phenotype in the enteric bacteria.

\section{Acetate uptake studies}

Acetate uptake was measured over as short a time period as possible (40 s, Fig. 1) in an attempt to distinguish acetate uptake from assimilation. B. stearothermophilus vegetative cells proved to be prone to lysis if cultures are held at room temperature or $37^{\circ} \mathrm{C}$, and also lyse during prolonged storage at $50^{\circ} \mathrm{C}$ without a carbon source; cells were kept above $42{ }^{\circ} \mathrm{C}$ whilst washing, and cells were assayed immediately after preparation. Even under optimized conditions for harvesting and washing cells, each cell suspension could only be assayed once significant lysis occurred in stored, unaerated cells during the $15 \mathrm{~min}$ required to complete an uptake experiment. The variation in activity of different batches of cells was generally within a twofold range.

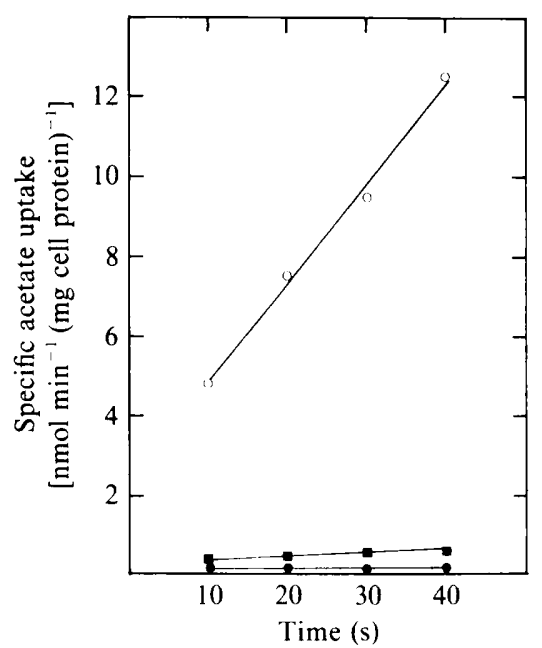

Fig. 1. Acetate uptake by $B$. stearothermophilus. Cells were incubated with $\left[2{ }^{14} \mathrm{C}\right]$ acetate, harvested at $10 \mathrm{~s}$ intervals onto membrane filters and washed. O, AM1116 (wild-type) cells; - AM1116 cells in the presence of $0.5 \mu \mathrm{M}-\mathrm{CCCP} ; \mathbf{\square}$, AM1048 (mutant) cells.

Results of a typical uptake experiment are shown in Fig. 1. The rate of uptake is linear over the $40 \mathrm{~s}$ period of sampling; experiments were routinely done with $38 \mu \mathrm{M}$ acetate; under these conditions the rate of acetate uptake in glucose-grown cells was $0.72 \mathrm{nmol} \mathrm{min}^{-1}$ (mg protein $)^{-1}$ whereas that in cells grown on a mixture of acetate and glucose was $8.9 \mathrm{nmol} \mathrm{\textrm {min } ^ { - 1 } ( \mathrm { mg } \text { protein) }}{ }^{-1}$, suggesting acetate-dependent induction. The addition of $0.5 \mu \mathrm{M}-\mathrm{CCCP}$ as a respiratory uncoupler led to inhibition, suggesting that the uptake process is active, or at least cannot be maintained in the absence of a proton gradient. Glyoxylate pathway mutants were also tested and these took up $\left[2-{ }^{14} \mathrm{C}\right]$ acetate at the same rate as the wild type.

Eight $\mathrm{Ace}^{-}$mutants which were neither glyoxylatecycle-defective nor isoleucine- and valine-requiring mutants were tested for their ability to take up acetate. Of these, mutant AM1048 was reproducibly defective in uptake (Fig. 1). To ensure that this apparent decrease in uptake was not due to a more rapid cell death in this strain, we measured uptake of $L-\left[1,4,5-{ }^{3} \mathrm{H}\right]$ leucine and of $\left[2-{ }^{14} \mathrm{C}\right]$ acetate simultaneously in a dual labelling experiment. Leucine was taken up by the mutant cells at about $50 \%$ of the wild-type rate; this is within the range that could be due to cell batch differences. The same cell suspension failed, as previously, to take up significant concentrations of acetate.

Acetate uptake in wild-type B. stearothermophilus was measured at increasing concentrations of acetate, to determine whether the system was saturable (Fig. 2). This did appear to be the case, although the variability between cell suspensions means that detailed kinetic analysis is impossible. A $V_{\max }$ of about $60 \mathrm{nmol} \mathrm{min}-1$ 


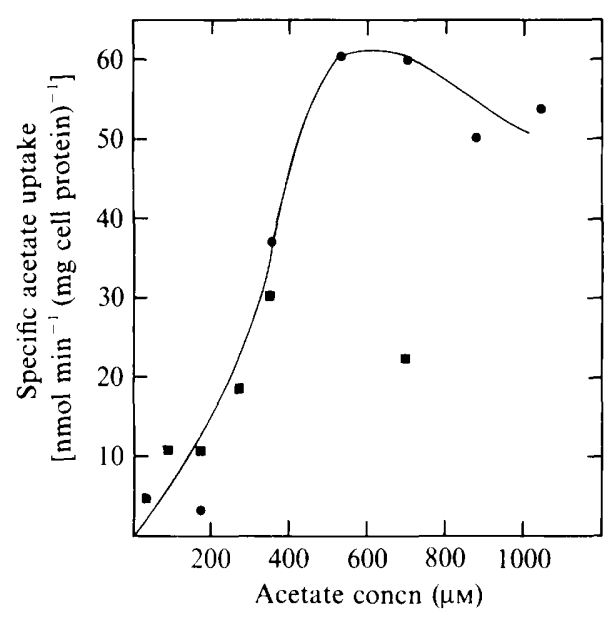

Fig. 2. Specific acetate uptake by $B$. stearothermophilus cells at various concentrations of acetate. Rates of acetate uptake were calculated from data as shown in Fig. 1; the graph includes data from experiments done on two separate occasions $(\sigma, \boldsymbol{\sigma})$. The $K_{\mathrm{m}}$, calculated as the concentration of acetate at which half the maximum velocity of acetate uptake was obtained, is approximately $300-350 \mu \mathrm{M}$-acetate, and the

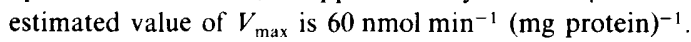

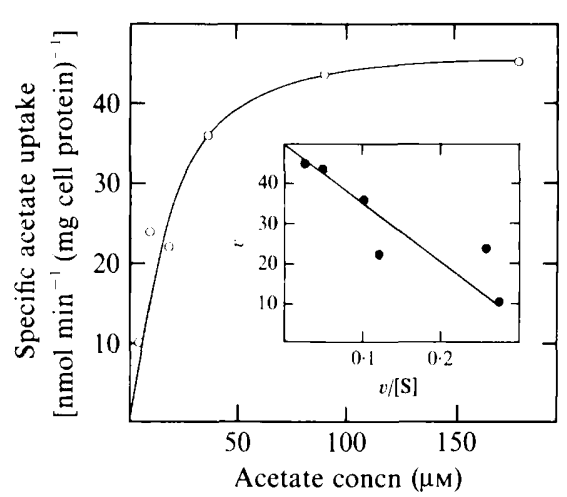

Fig. 3. Specific acetate uptake by succinate-grown $E$. coli cells at various concentrations of acetate. Inset: Eadie-Hofstee plot of the data in the main figure, giving estimates of $K_{\mathrm{m}}=15 \mu \mathrm{M}$ and $V_{\max }=50 \mathrm{nmol}$ $\min ^{-1}$ (mg protein) ${ }^{-1}$.

(mg protein) $)^{-1}$ was estimated; the apparent $K_{\mathrm{m}}$ at halfmaximum velocity was about $300-350 \mu \mathrm{M}$-acetate.

Following the discovery of a possible $B$. stearothermophilus acetate transport system, we tested whether $E$. coli possesses a similar system. Fig. 3 shows that acetate uptake is saturable in succinate-grown $E$. coli cells. The kinetics appear more classically hyperbolic; the $K_{\mathrm{m}}$ for acetate uptake at $37^{\circ} \mathrm{C}$ in $E$. coli was about $15 \mu \mathrm{M}$ and

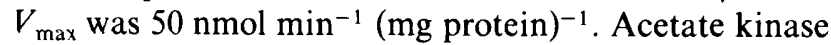
and phosphotransacetylase mutants of $E$. coli transported acetate at the same rate as the wild-type (results not shown), confirming that the uptake system was independent of these enzymes.

\section{Discussion}

The spectrum of $B$. stearothermophilus mutants with defects in acetate metabolism obtained in this study differs from those obtained previously in $E$. coli and $S$. typhimurium, as no acetate kinase or phosphotransacetylase mutants were obtained. Several explanations for this are possible. There may be more than one enzyme with these activities, or an alternative biochemical pathway may exist to convert acetate to acetyl-CoA. Alternatively, lesions in pta or ack genes may affect growth on glucose or other substrates as these enzymes may be required to recycle $\mathrm{CoA}$ in conditions of carbon excess, when acetate is excreted. Brown et al. (1977) have shown that pta mutants of $E$. coli excrete virtually no acetate into the growth medium, but these strains can grow on glucose. Van Dyk \& LaRossa (1987) have shown that pta and $a c k$ gene products are also essential in $\alpha$-ketobutyrate metabolism in $S$. typhimurium, converting propionylCoA to propionyl phosphate and propionyl phosphate to propionate, respectively. A sulphometuron-methyl-induced build-up of $\alpha$-ketobutyrate during growth of $S$. typhimurium in glucose minimal medium is lethal (LaRossa et al., 1987; Van Dyk \& LaRossa, 1987), but there is no reason to suppose that such a build-up would occur in B. stearothermophilus cells grown on glucose, succinate or lactate.

The glyoxylate pathway mutants of $B$. stearothermophilus are analogous to those found in $E$. coli and $S$. typhimurium. It is likely, therefore, that the isocitrate lyase and malate synthase (icl and mas) genes form an operon in $B$. stearothermophilus which is transcribed from $m a s$ to $i c l$ analogous to those of $E$. coli (Cortay et al., 1988 ) and S. typhimurium (Wilson \& Maloy, 1987).

For a significant proportion (about $35 \%$ ) of $\mathrm{Ace}^{-}$ mutants, it was not possible to identify any enzymological defect. There must be additional components essential to acetate-specific metabolism, but as exemplified by the isoleucine/valine-requiring mutants, not all may be directly associated with the catabolic pathway. Guest (1979) reported the isolation of acetate-negative fluoroacetate-resistant mutants which were wild-type for both acetate kinase and phosphotransferase; these mutants, designated $f a c B$, mapped close to ack and pta, suggesting a relationship with acetate metabolism.

Our results suggest that an active acetate uptake system is present in B. stearothermophilus. Brown et al. (1977) showed that an inducible acetyl-CoA synthetase, acetate kinase and phosphotransacetylase are involved in the long-term assimilation of acetate in $E$. coli, but there have been no reports of measurement of acetate transport.

It has been suggested that weak acids such as acetate permeate the cytoplasmic membrane by passive diffu- 
sion in their undissociated form (Kell et al., 1981). Boenigk et al. (1989), however, reported a carriermediated acetate transport system in Acetobacterium woodii, which excretes copious amounts of acetate. The apparent $K_{\mathrm{m}}$ of this transport system was $850 \mu \mathrm{M}$. The actual mechanism of transport was not established, but it could involve either facilitated diffusion of the acid or a proton/acetate symport.

The $B$. stearothermophilus acetate transport system appears to have a relatively low affinity for acetate, but it is acetate-inducible and uncoupler-sensitive, although some caution is necessary in interpreting the effect of uncouplers on transport systems in intact cells, as they may affect intracellular $\mathrm{pH}$, resulting in indirect effects. The transport systems of $B$. stearothermophilus and $A$. woodii are both low affinity systems whose concentration dependence shows sigmoidal kinetics. In contrast, the acetate transport system detected in $E$. coli is of much higher affinity; the maximum uptake rates in $E$. coli and $B$. stearothermophilus are much higher than that reported for $A$. woodii.

The importance of the uptake system in the catabolism of acetate in B. stearothermophilus is suggested by the Ace $^{-}$phenotype of AM1048. It was not possible to test whether fatty acids, metabolized via acetyl-CoA, could act as a carbon source, as the wild-type parent proved unable to grow on oleate. Both wild-type and mutant could, however, grow on minimal medium containing ethanol, another two-carbon compound that is likely to be metabolized via acetyl-CoA. The mutant formed somewhat smaller colonies on ethanol than did the wildtype: this could be an indirect result of the acetate transport defect, or might reflect a second residual mutation in the strain. Despite this complication, the ability to grow on ethanol suggests that the strain can still metabolize internal acetate or acetyl-CoA.

The evidence presented argues strongly that both $B$. stearothermophilus and $E$. coli possess specific transport systems for acetate, although a full analysis of either uptake system is beyond the scope of this paper.

The behaviour of mutant AM1048, which failed to take up acetate despite having normal levels of acetate kinase and phosphotransacetylase, argues that in $B$. stearothermophilus the observed uptake of radiolabelled acetate is not the result of simple diffusion followed by rapid metabolism, although it would have been helpful to be able to undertake transport studies in a metabolically blocked strain. The $E$. coli uptake system was of much higher affinity; here no transport mutant was available, but metabolically blocked strains showed the same uptake behaviour as the wild type. The low $K_{\mathrm{m}}$ of the uptake system, at $15 \mu \mathrm{M}$, was also very different from the published $K_{\mathrm{m}}$ values of the enzymes that might be responsible for acetate assimilation - acetate kinase and
acetyl-CoA synthase have $K_{\mathrm{m}}$ values of $7 \mathrm{~mm}$ and $200 \mu \mathrm{M}$, respectively (Fox \& Roseman, 1986; Brown et al., 1977). The two systems may have different roles in the two organisms; as already discussed, bacilli excrete acetate during growth on rich media or glucose, and a relatively high $K_{\mathrm{m}}$ would be appropriate for a system designed to effect excretion of excess intracellular acetate, whereas the low $K_{\mathrm{m}}$ of the $E$. coli system might suggest an efficient uptake system to scavenge extracellular acetate.

We thank Professor D. W. Tempest for useful discussion, Professor J. R. Guest for donating E. coli strains, and Dr D. J. Kelly for advice on uptake experiments. P. R. M. was the recipient of an SERC studentship.

\section{References}

Boenigk, R., Durre, P. \& Gotrschalk, G. (1989). Carrier-mediated acetate transport in Acetobacterium woodii. Archives of Microbiology 152, 589-593.

BRADFORD, M. M. (1976). A rapid and sensitive method for the quantitation of microgram quantities of protein utilizing the principle of protein-dye binding. Analytical Biochemistry 72, 248254.

Brown, T. D. K., Jones-Mortimer, M. C. \& Kornberg, H. L. (1977). The enzymic interconversion of acetate and acetyl-CoA in E. coli. Journal of General Microbiology 102, 327-336.

Cortay, J. C., Bleicher, F., Rieul, C., Reeves, H. C. \& Cozzone, A. J. (1988). Nucleotide sequence and expression of the ace $K$ gene coding for isocitrate dehydrogenase kinase/phosphatase in Escherichia coli. Journal of Bacteriology 170, 89-97.

Dailey, F. E. \& Cronan, J. E. (1986). Acetohydroxy acid synthase I, a required enzyme for isoleucine and valine biosynthesis in $E$. coli $\mathrm{K}-12$ during growth on acetate as sole carbon source. Journal of Bacteriology 165, 453-460.

Dailey, F. E., Cronan, J. E., JR \& Maloy, S. R. (1987). Acetohydroxy acid synthase $\mathrm{I}$ is required for isoleucine and valine biosynthesis by Salmonella typhimurium LT2 during growth on acetate or long-chain fatty acids. Journal of Bacteriology 169, 917-919.

Epstein, I. \& Grossowicz, N. (1969). Prototrophic thermophilic Bacillus: isolation, properties, and kinetics of growth. Journal of Bacteriology 99, 414-417.

Evans, C. G. T., Herbert, D. \& Tempest, D. W. (1970). The continuous cultivation of micro-organisms. 2. Construction of a chemostat. Methods in Microbiology 2, 275-327.

Fox, D. K. \& Roseman, S. (1986). Isolation and characterization of homogeneous acetate kinase from Salmonella typhimurium and Escherichia coli. Journal of Biological Chemistry 261, 13487-13497.

Glusker, J. P. (1971). Aconitase. In The Enzymes, 3rd edn, vol. 5, pp. 413-439. Edited by P. D. Boyer. New York \& London: Academic Press.

GuEst, J. R. (1979). Anaerobic growth of Escherichia coli K 12 with fumarate as terminal electron acceptor. Genetic studies with menaquinone and fluoroacetate-resistant mutants. Journal of General Microbiology 115, 259-271.

ITO, J. \& SPIZIZEN, J. (1971). Increased rate of asporogenous mutants following treatment of Bacillus subtilis with ethyl methane sulphonate. Mutation Research 13, 93-96.

Kell, D. B., PeCK, M. W., Rodgers, G. \& Morris, J. G. (1981). On the permeability to weak acids and bases of the cytoplasmic membrane of Clostridium pasteurianum. Biochemical and Biophysical Research Communications 99, 81-88.

LaRossa, R. A., VAN DYK, T. K. \& SMulski, D. R. (1987). Toxic accumulation of $\alpha$-ketobutyrate caused by inhibition of the branched chain amino acid biosynthetic enzyme acetolactate synthase in Salmonella typhimurium. Journal of Bacteriology 169, 1372-1378. 
Levine, S. M., ARdeshir, F. \& Ferro-Luzzi Ames, G. (1980) Isolation and characterization of acetate kinase and phosphotransacetylase mutants of Escherichia coli and Salmonella typhimurium. Journal of Bacteriology 143, 1081-1085.

Liao, H., McKenzie, T. \& Hageman, R. (1986). Isolation of a thermostable enzyme variant by cloning and selection of a thermophile. Proceedings of the National Academy of Sciences of the United States of America. 83, 576-579.

Mager, J., Goldblum-Sinai, J. \& Blank, I. (1955). Effect of fluoroacetic acid and allied fluoroanalogues on growth of $E$. coli. Journal of Bacteriology 70, 320-325.

NeCasek, J., Pikalek, P. \& Drobnik, J. (1966). The mutagenic effect of prolonged treatment with ethyl methane sulphonate. Mutation Research 4, 409-413.

Nishimura, J. S. \& Griffith, M. J. (1981). Acetate kinase from Veillonella alcalescens. Methods in Enzymology 71, 311-313.
Pennock, J. \& Tempest, D. W. (1988). Metabolic and energetic aspects of the growth of Bacillus stearothermophilus in glucose-limited and glucose sufficient chemostat culture. Archives of Microbiology 150, $452-459$.

ReEves, H. C., Rabin, R., Wegener, W. S. \& AJl, S. J. (1971). Assays of enzymes of the tricarboxylic acid and glyoxylate cycles. Methods in Microbiology 6A, 425-462.

VAN DYK, T. K. \& LARossA, R. A. (1987). Ivolvement of ack-pta operon products in $\alpha$-ketobutyrate metabolism by Salmonella typhimurium. Molecular and General Genetics 207, 435-440.

WILSON, R. B. \& MALOY, S. R. (1987). Isolation and characterization of Salmonella typhimurium glyoxylate shunt mutants. Journal of Bacteriology 169, 3029-3034.

WOFFord, N. Q., BEATY, P. S. \& MCINERney, M. J. (1986). Preparation of cell-free extracts and the enzymes involved in fatty acid metabolism in Syntrophomonas wolfei. Journal of Bacteriulogy 167, 179-185. 